\title{
Content validity of scenes from declarative tactical knowledge test for attack situation in beach volleyball - DTKAT-BV
}

\author{
Validação de conteúdo do teste de conhecimento tático \\ declarativo para a situação de ataque no voleibol de \\ praia - TCTDA-VP
}

Validación de contenido del test de conocimiento táctico declarativo para la situación de ataque en voleibol de playa - TCTDA-VP

\footnotetext{
(iD) Jarbas Rállison Domingos-Gomes Universidade Federal da Paraíba, João Pessoa, Paraíba, Brasil. jarbasrallison@hotmail.com

(iD) Raianne de Brito Grisi Universidade Federal da Paraíba, João Pessoa, Paraíba, Brasil. raiannegrisi@outlook.com

iD (9) Júlio Cesar Gomes da Silva Universidade Federal da Paraíba, João Pessoa, Paraíba, Brasil. juliociesar123@gmail.com

iD (9) Vitor Bruno Cavalcanti Torres Universidade Federal da Paraíba, João Pessoa, Paraíba, Brasil. brunotorresedf@gmail.com

(iD) Henrique de Oliveira Castro Universidade Federal de Mato Grosso, Cuiabá, Mato Grosso, Brasil. henriquecastro88@yahoo.com.br

iD Gilmário Ricarte Batista Universidade Federal da Paraíba, João Pessoa, Paraíba, Brasil. cajagr@gmail.com
} 
Abstract: The aim of the study was to establish the content validity of scenes from the Declarative Tactical Knowledge Attack Test in Beach Volleyball (DTKAT-VB). Four experts evaluated 32 attack scenes in real situations of BV game through were assessed the Content Validity Coefficient (CVC) through criteria of language clarity, practical relevance and item representativeness. The results showed that all scenes assessed obtained CVC values greater than 0.80 for all criteria[image clarity (CVC - 0.98); practical relevance (CVC - 0.97); item representativeness (CVC - 0.94)], except for one scene, which was excluded. The 31 scenes validated using the CVC enables the evaluation of the declarative tactical knowledge, assisting in the planning of the teaching-learning-training processes of beach volleyball athletes.

Keywords: Validation Studies. Sport Training. Psychometry. Beach Volleyball.

Resumo: O objetivo do estudo foi estabelecer a validade de conteúdo das cenas do Teste de Conhecimento Tático Declarativo do Ataque no Voleibol de Praia (TCTDA-VP). Quatro especialistas avaliaram 32 cenas de ataque em situações reais de jogo de VP foram avaliadas pelo Coeficiente de Validade de Conteúdo (CVC) por meio de critérios de clareza de linguagem, relevância prática e representatividade dos itens. Os resultados mostraram que as cenas avaliadas obtiveram valores de CVC maiores que 0,80 para todos os critérios [clareza da imagem (CVC 0,98); relevância prática (CVC - 0,97); a representatividade do item (CVC - 0,94)], com exceção de uma cena, sendo assim excluída. As 31 cenas validadas por meio do CVC possibilitam a avaliação do conhecimento tático declarativo, auxiliando no planejamento dos processos de ensinoaprendizagem-treinamento de atletas do voleibol de praia.

Palavras-chave: Estudos de Validação. Treinamento Esportivo. Psicometria. Voleibol de Praia.

Resumen: El objetivo del estudio fue estabelecer la validación de contenido de las escenas del Teste de Conocimiento Táctico Declarativo del Ataque en el Voleibol de Playa - TCTDA-VP. Cuatro especialistas 
evaluaron 32 escenas de ataque en situaciones reales de juego de VP através del Coeficiente de Validez de Contenido (CVC) através de criterios de claridad del idioma, relevancia práctica y representatividad del elemento. Los resultados mostraron que para todos los criterios [claridad de imagen (CVC - 0.98); relevancia práctica (CVC - 0.97); representatividad del elemento (CVC - 0,94)], obtuvieron un CVC superior a 0,80, excepto por una escena, quedando así excluida. Las 31 escenas validadas por el CVC possibilitaron la evaluación del conocimiento táctico declarativo ayudando em la planificación de los processos de enseñanza-aprendizajetreinamiento de los deportistas de voleibol de playa.

Palabras-clave: Estudios de Validación. Entrenamiento Esporivo. Psicometría. Voleibol de Playa.

Submetido em: 26-05-2021

Aceito em: 18-08-2021 
Content validity of scenes from declarative tactical knowledge test for attack situation in beach... Jarbas Rállison Domingos-Gomes • Raianne de Brito Grisi • Júlio Cesar Gomes da Silva • Vitor Bruno Cavalcanti Torres • Henrique de Oliveira Castro • Gilmário Ricarte Batista

\section{Introduction}

Unpredictability, randomness and variability are inherent characteristics of team sports, such as beach volleyball (BV). In this modality, the attack skill stands out among other skills (serve, reception, setting, defense and block), due to the multiple decisionmaking (DM) alternatives on how to perform the technique, compared to the other skills (MESQUITA; TEIXEIRA, 2004). The spike, dunk, and powerful attack types, among others, are possible choices that athletes can make when performing an attack. In addition, studies have shown that attackis a predictor of success in $\mathrm{BV}$, since winning teams excel losers in the performance of this skill (GEORGE; PANAGIOTIS, 2008, GIATSIS; TZETZIS, 2003, PALAO; ORTEGA, 2015). Thus, attack presents itself as a fundamental skill for high performance in BV.

In order to execute good attack, the athlete needs more than good technique, since DM processes that relies on tactical knowledge are necessary to perform the skill successfully and to achieve high game effectiveness (COSTA et al., 2002). DM reflects the ability of an individual to choose the best alternative at the right time, given the many possibilities of choice (RAAB, 2003, 2007, 2015; RAAB; GIGERENZER, 2005; WILLIAMS et al., 2012), based on several cognitive processes, such as tactical knowledge, attention, anticipation, memory and visual perception (MURGIA et al., 2014; TENENBAUM; FILHO, 2017). Accordingly, team sports" coaches are concerned with developing athletes" DM during training sessions .

The ability to make decisions in team sports relates to the processes of declarative tactical knowledge (DTK) (ANDERSON, 1982), which are declared facts "of what to do" in certain game situations. These statements are thought to provide the possibility to assess DM (GRECO, 2006). DTK indentifies with "knowing", "knowing what to do", and refers to knowledge that athletes have of skills and strategies of the game (ANDERSON, 1982; FRENCH; THOMAS, 1987; GAMEIRO et al., 2021; WILLIAMS; DAVIDS, 1995). 
Content validity of scenes from declarative tactical knowledge test for attack situation in beach... Jarbas Rállison Domingos-Gomes • Raianne de Brito Grisi • Júlio Cesar Gomes da Silva • Vitor Bruno Cavalcanti Torres • Henrique de Oliveira Castro • Gilmário Ricarte Batista

Indeed, studies have shown moderate or high correlations between DTK and DM, showing improvements in ability to perform actions in the game (BLOMSQVIST et al., 2005; CASTRO et al., 2016; MCPHERSON; THOMAS, 1989). In this context, the application of instruments to measure DTK becomes necessary to assess the athletes tactical capacity (GAMEIRO et al., 2021). Considering the direct nature of this relation, DTK tests are used to evaluate the DM of volleyball athletes (CASTRO et al., 2016, 2017, 2019, 2020; GRISI et al., 2021) and coaches (COSTA et al., $2018 \mathrm{ab}$ ).

In indoor volleyball, Costa et al. (2016) used the Content Validity Coefficient (CVC) for the validation of scenes containing extremity attacks, central attacks, settings and blocks in a DTK test. However, although indoor volleyball shows many similarities with $\mathrm{BV}$, the game dynamics between the two modalities are very different, which indicates the need for a specific DTK test for BV (TILP; WAGNER; MÜLLER, 2008).

Thereby a specific DTK test must be created and validated for BV with the purpose of assisting professionals in training and assessing cognitive processes such as DM in this sport modality. However, to the best of the authors' knowledge, no work have validated BV attack scenes with the intent of creating a DTK test. Thus, the aim of the study was to establish the content validity of scenes from the Declarative Tactical Knowledge Attack Test in Beach Volleyball (DTKAT-VB).

\section{Materials and Methods}

\section{Sample}

The sample consisted of four experts in beach volleyball, following the recommendation suggested by Hernández-Nieto (2002). The following inclusion criteria were used: (1) Having at least 10 years of experience in beach volleyball; (2) be a beach volleyball 
Content validity of scenes from declarative tactical knowledge test for attack situation in beach... Jarbas Rállison Domingos-Gomes • Raianne de Brito Grisi • Júlio Cesar Gomes da Silva • Vitor Bruno Cavalcanti Torres • Henrique de Oliveira Castro • Gilmário Ricarte Batista

coach at the time of the data collection; and (3) not participating in any stage of the study other than the validation of scenes. With regard to time of experience, the mean and standard deviation of the participants was 13.5 \pm 3.4 . According Ericsson et al. (2006), experts coaches in the modality must have experience of at least 10 years. Table 1 shows the profile of specialists participating in this study.

Table 1. Representativeness panel of BV experts.

\begin{tabular}{|c|c|c|}
\hline Description & Training / performance in beach volleyball & Experience \\
\hline Expert 1 & $\begin{array}{l}\text { PhD. Minas Gerais state champion in U-17, U-19 and U-21 } \\
\text { categories. Level II BV Coach. }\end{array}$ & 18 years \\
\hline Expert 2 & $\begin{array}{l}\text { World U-19 champion and World U-21 two-times champion, } \\
\text { Brazilian U-19 and U-21 champion. Level II BV Coach. }\end{array}$ & 14 years \\
\hline Expert 3 & $\begin{array}{l}\text { World U-21 and U-19 champion, Brazilian U-23 champion and } \\
\text { South American champion in senior category. Level II BV Coach. }\end{array}$ & 10 years \\
\hline Expert 4 & $\begin{array}{l}\text { Master's degree. Brazilian U-19 champion; 3rd place in the } \\
\text { South American championship; 9th place in the world U-19 } \\
\text { championship; Level II BV Coach. }\end{array}$ & 12 years \\
\hline
\end{tabular}

The present study was approved by the Ethics Research Committee of the Health Sciences Center of Federal University of Paraíba (protocol No. 2.614.432), meeting all the requirements of the National Health Council - Resolution 466/12. It is important to highlight that the present study is part of a macro project and only part of the data from this project was used.

\section{Procedures}

The research consisted of three stages: in the first, attack scenes were prepared and selected; after that, the ecological 
Content validity of scenes from declarative tactical knowledge test for attack situation in beach... Jarbas Rállison Domingos-Gomes • Raianne de Brito Grisi • Júlio Cesar Gomes da Silva • Vitor Bruno Cavalcanti Torres • Henrique de Oliveira Castro • Gilmário Ricarte Batista

validity of the scenes was assessed by experts; and, finally, scenes were validated using the CVC values calculated. Thirty-two attack scenes were selected, with the video starting with the opponent's serve and then following to receiving, setting and attack, lasting from 4 to 7 seconds. All scenes had the presence of the opposing team's block and there was no freezing of the images. These scenes were taken from the Men's World Circuit Games held in 2018. In all scenes, the camera was positioned in a way that all dimensions of the court were captured.

The ecological validity analysis of the scenes was verified through the experts' choices, which should reflect the same actions as the ones performed by the athletes in the scenes (PASQUALI, 2007). 32 scenes presented ecological validaty, representing the choice of experts in agreement with the action performed by athletes in scenes that culminated in score. After these analysis, as a criterion used by authors, for the CVC evaluation, the 32 scenes with ecological validity were used to calculate CVC.

Within the theoretical procedures proposed by Pasquali (2007) for the elaboration of psychometric instruments, the semantic analysis of items and the analysis of experts aim to verify the representativeness of the construct through the items. In this sense, the specialized literature recommends the use of CVC (COSTA et al, 2016; GRECO et al, 2014), in order to investigate the representativeness level of the construct using validation of concepts of image clarity, practical relevance and item representativeness. That is, it is verified if the instrument measures exactly what it proposes, in terms of its content (ROBERTS et al., 2006). Thus, in order to verify reproducibility, experts evaluated scenes according to procedures presented by Hernández-Nieto (2002) regarding the criteria of image clarity, practical relevance and item representativeness for each of the scenes. Table 2 presents the evaluation criteria for scenes selection. 
Content validity of scenes from declarative tactical knowledge test for attack situation in beach... Jarbas Rállison Domingos-Gomes • Raianne de Brito Grisi • Júlio Cesar Gomes da Silva • Vitor Bruno Cavalcanti Torres • Henrique de Oliveira Castro • Gilmário Ricarte Batista

Table 2. Descriptions and questions of test items.

\begin{tabular}{|c|c|c|c|}
\hline Item & Image clarity & Practical relevance & $\begin{array}{l}\text { Item } \\
\text { representativeness }\end{array}$ \\
\hline Description & $\begin{array}{l}\text { The quality of images } \\
\text { from the scenes will be } \\
\text { evaluated considering } \\
\text { the population of BV } \\
\text { athletes and experts } \\
\text { who will later answer it. }\end{array}$ & $\begin{array}{l}\text { The relevance of the scene } \\
\text { will be evaluated in terms } \\
\text { of representing decision- } \\
\text { making situations in the BV } \\
\text { game. }\end{array}$ & $\begin{array}{l}\text { The level of } \\
\text { representation of the } \\
\text { cognitive processes } \\
\text { that were of interest } \\
\text { in the scenes will be } \\
\text { evaluated. }\end{array}$ \\
\hline Question & $\begin{array}{l}\text { Are the images clear? } \\
\text { Is it possible to see the } \\
\text { ball, the players, the } \\
\text { net and the court lines } \\
\text { clearly in the scene? }\end{array}$ & $\begin{array}{l}\text { Do you believe that } \\
\text { this scene represent } \\
\text { appropriate situations to } \\
\text { assess player's decision- } \\
\text { making in a BV game? }\end{array}$ & $\begin{array}{l}\text { Do you believe that } \\
\text { this scene allows the } \\
\text { analysis of a player's } \\
\text { decision-making and } \\
\text { the relevant signals } \\
\text { that lead to it? }\end{array}$ \\
\hline
\end{tabular}

Experts assessed scenes in each of the criteria using a 5-point Likert scale $(1=$ very low, $2=$ low $3=$ average, $4=$ high, and $5=$ very high), following the questions from Table 2. The responses were used to calculate the CVC for each item, indicating the experts' degree of agreement for each item in the scenes analyzed. After this process, the scenes that obtained agreement values lower than 0.80 were excluded and the scenes that obtained higher values than 0.80 were maintained.

\section{Statistical analysis}

The experts' responses regarding scenes were tabulated and analyzed in the Microsoft Office Excel 2010 software using the CVC formula and its descriptions. CVC was calculated for each scene $\left(\mathrm{CVC}_{\mathrm{c}}\right)$, total $\left(\mathrm{CVC}_{\mathrm{t}}\right)$ and corrected $\left(\mathrm{CVC}_{\mathrm{tc}}\right)$, based on scores from the four experts. The average of scores for each item was calculated as follows: 
Content validity of scenes from declarative tactical knowledge test for attack situation in beach... Jarbas Rállison Domingos-Gomes • Raianne de Brito Grisi • Júlio Cesar Gomes da Silva • Vitor Bruno Cavalcanti Torres • Henrique de Oliveira Castro • Gilmário Ricarte Batista

1) The experts' scores were calculated as proposed by Hernández-Nieto (2002, p.128) (M):

$$
M x=\frac{\sum_{i=1}^{j} x i}{l}
$$

Where $M_{x}$ is the average scores for each item, $\Sigma x_{i}$ represents the sum of experts' scores and $\mathrm{J}$ represents the number of experts who evaluated the item.

2) Based on the average, CVC was calculated for each item (HERNÁNDEZ-NIETO, 2002, p.128) (CVC):

$$
C V C_{i}=\frac{M x}{V \max }
$$

Where $\mathrm{V}_{\max }$ represents the maximum value that i could receive.

3) Error $\left(P_{e}\right)$ was also calculated to account for possible evaluation bias for each item (HERNÁNDEZ-NIETO, 2002, p.131):

$$
P e_{i}=\left(\frac{1}{I}\right)^{\prime}
$$

4) Then, the final $\mathrm{CVC}$ of each item $\left(\mathrm{CVC}_{\mathrm{ei}}\right)$ was calculated (HERNÁNDEZ-NIETO, 2002, p.133):

$$
\overline{C V C_{\text {er. }}=C V C_{i}-P e_{i}}
$$

5) In the calculation of the $\mathrm{CVC}_{t}$ and corrected CVC $\left(\mathrm{CVC}_{\mathrm{tc}}\right)$, for each of the items (image clarity, practical relevance, and item representativeness), ( $p$ 143) the following equation was used: 
Content validity of scenes from declarative tactical knowledge test for attack situation in beach... Jarbas Rállison Domingos-Gomes • Raianne de Brito Grisi • Júlio Cesar Gomes da Silva • Vitor Bruno Cavalcanti Torres • Henrique de Oliveira Castro • Gilmário Ricarte Batista

$$
\overline{C V C_{t}=M C V C_{i}-M P e_{i}}
$$

Where $\mathrm{MCVC}_{\mathrm{i}}$ represents the mean $\mathrm{CVCs}$ values of the test items and $\mathrm{Mpe}_{i}$ represents the mean error of the test items.

\section{Results}

The 32 attack scenes presented initial $\mathrm{CVC}_{\mathrm{t}}$ scores of 0.95 for criteria of image clarity and practical pertinence. Ultimately, $\mathrm{CVC}_{\mathrm{tc}}$ values of 0.98 and 0.97 , were shown for image clarity and practical pertinence criteria respectively, as shown in Table 3. Regarding item representativeness, a $C V C_{\text {tc }}$ value of 0.94 was found. Nevertheless, one item (scene 1) presented a $\mathrm{CVC}_{\mathrm{t}}$ value of 0.79 which, is below those considerable acceptable by literature $(<0.8)$. Therefore, this scene was excluded.

Table 3. Content Validity Coefficient Values (CVC) obtained from experts' evaluation of the attack scenes.

\begin{tabular}{cccc}
\hline Criterion evaluated & $\begin{array}{c}\text { Items without } \\
\mathbf{C V C}_{\mathbf{t}}(\mathbf{0 . 8 0 )}\end{array}$ & $\mathbf{C V C}_{\mathbf{t c}}$ & $\begin{array}{c}\mathbf{C V C}_{\mathbf{t c}} \\
\mathbf{e x c l}\end{array}$ \\
\hline Image clarity & 32 & 0.98 & 0 \\
Practical pertinence & 32 & 0.97 & 0 \\
Item representativeness & 31 & 0.94 & $\begin{array}{c}\text { Scene 1 } \\
\left(\mathrm{CVC}_{\mathbf{t}}=0.79\right)\end{array}$ \\
\hline
\end{tabular}

CVCt = Total Content Validity Coefficient for item; CVCtc = Total Content Validity Coefficient for item adjusted

\section{Discussion}

The aim of the study was to establish the content validity of scenes from the Declarative Tactical Knowledge Attack Test in 
Content validity of scenes from declarative tactical knowledge test for attack situation in beach... Jarbas Rállison Domingos-Gomes • Raianne de Brito Grisi • Júlio Cesar Gomes da Silva • Vitor Bruno Cavalcanti Torres • Henrique de Oliveira Castro • Gilmário Ricarte Batista

Beach Volleyball (DTKAT-VB). The results showed that 31 of the 32 proposed attack scenes obtained satisfactory CVC values using the image clarity, practical relevance and item representativeness criteria. Therefore, after CVC calculation, content validity was confirmed in 31 scenes that will be used in the DTKAT-BV to assess DM and DTK in BV.

Based on the assumption of Costa et al. (2002), which proposes that six to 13 scenes would be an ideal number of scenes to elaborate a DTK test, 32 attack scenes were selected in the present study. Overall, 31 attack scenes were considered valid, which is in accordance with Pasquali's (1999) recommendations, which suggested that the test should have at least 20 items so that the semantic representation of the construct is stable and well represented.

Other studies have proposed to investigate this type of validation in collective sports. To illustrate, Aburachid and Greco (2011) validated scenes in tennis and Costa et al. (2016) validated volleyball scenes that comprised extremity attacks, center attacks, settings and block actions. Our findings are in line with findings from these studies, since all studies showed validated scenes with CVC values above 0.80 for image clarity, practical relevance and item representativeness. Additionally, the number of scenes validated for constructing the declarative tactical tests was above 20 scenes in all cases.

Similarly, other studies have used the CVC methodology to validate specific actions in handball, futsal and basketball (GRECO et al., 2014), in soccer and futsal (CASTRO et al., 2015) and in basketball (MORALES et al., 2012). In short, the results of these studies also reported satisfactory CVC results $(>0.80)$.

In the present study, only attack scenes were validated. This is justified by the fact that attack is one of the main skills related to $\mathrm{DM}$ in $\mathrm{BV}$, due to the many motor possibilities that can be performed. Moreover, the success rate in executing this action during the game is positively associated with the match outcome 
Content validity of scenes from declarative tactical knowledge test for attack situation in beach... Jarbas Rállison Domingos-Gomes • Raianne de Brito Grisi • Júlio Cesar Gomes da Silva • Vitor Bruno Cavalcanti Torres • Henrique de Oliveira Castro • Gilmário Ricarte Batista

(GIATSIS; TZETZIS, 2003), which makes this skill the most decisive to win the matches. The other abilities are expected to rely less on decision-making processes to be performed. For example, in the serve skill, the athlete has time to think where to direct the ball, and depending on the opponent, game strategies can be elaborated in advance. At reception, setting, defending, and blocking DM options are limited and somehow predetermined.

The validated scenes in the present study could be used in a declarative tactical knowledge test to evaluate DM in BV athletes. Considering the fact thata tactical knowledge test must contain 6 to 13 validated scenes (COSTA et al., 2002), the scenes validated in this study may allow the elaboration of more than one declarative tactical knowledge test.

The study was limited to the content validity of oficial highperformance beach volleyball game scenes in the adult male category, which in a way restricts the use of these scenes with female volleyball players. Tus, further studies should develop and validate specifc tests for female volleyball athletes with similar situational constraints. In addition, the stratifcation of the level of difculty of each scene presented by the test becomes interesting, allowing creating tests according to the level of athletes analyzed.

\section{Conclusion}

This study indicates that the attack scenes of the DTKAT-BV are validated to CVC, and thus, can be used to create an instrument to evaluate the declarative tactical knowledge of beach volleyball. Among other possibilities, this instrument may be used to investigate differences in declarative tactical knowledge regarding age, practice time, skills proficiency, and other aspects related to performance in the modality.

Thus, the validation of attack scenes from the DTKAT-BV may contribute to the improvement of pedagogical processes and 
Content validity of scenes from declarative tactical knowledge test for attack situation in beach... Jarbas Rállison Domingos-Gomes • Raianne de Brito Grisi • Júlio Cesar Gomes da Silva • Vitor Bruno Cavalcanti Torres • Henrique de Oliveira Castro • Gilmário Ricarte Batista

to performance in this sport modelity. The application of attack scenes is an effective way to assess and monitor the development of DTK, thus improving the teaching-learning-training process in BV.

\section{References}

ABURACHID, L. M. C.; GRECO, P. J. Scene content validation in a tactical knowledge test of tennis, Estudos de Psicologia, v. 28, n. 2, p. 261-268, 2011. DOI: 10.1590/S0103-166X2011000200013 ANDERSON, R. J. Acquisition of Cognitive Skill. Psychological Review, v. 89, p. 369-406, 1982. DOI: 10.1037/0033-295X.89.4.369 BALBINOTTI, M. A. A.; BENETTI, C.; TERRA, P. R. S. Translation and validation of the Graham-Harvey survey for the Brazilian context. International Journal of Managerial Finance, v. 3, n. 1, p. 26-48, 2007. DOI: 10.1108/17439130710721644

BLOMQVIST, M.; VÄNTTINEN, T.; LUHTANEN, P. Assessment of secondary school students' decision-making and game-play ability in soccer. Physical Education \& Sport Pedagogy, v. 10, n. 2, p. 107-119, 2005. DOI: 10.1080/17408980500104992

CASTRO, H.O.; AGUIAR, S.S.; CLEMENTE, F.M.; LIMA, R.F.; OLIVEIRA, V.; RIBAS, S.; PEDROSA, G.F.; LAPORTA, L.; COSTA, G.C.T. Association between motivation and decision-making in under-18 male volleyball players. TRENDS in Sport Sciences, v. 27, n. 4, p. 183-189, 2020. DOI: 10.23829/TSS.2020.27.4-1

CASTRO, H.O.; COSTA, G.C.T.; LAGE, G.M.; PRAÇA, G.M.; FERNÁNDEZ-ECHEVERRÍA, C.; ARROYO, M.P.; GRECO, P.J. Visual behaviour and decision-making in attack situations in volleyball.

Revista Internacional de Medicina y Ciencias de la Actividad Física y el Deporte, v. 19, n. 75, p. 565-578, 2019. DOI: 10.15366/ rimcafd2019.75.012

CASTRO, H.O.; COSTA, G.C.T.; PRAÇA, G.M.; CAMPBELL, C.S.G.; GRECO, P.J. Análise das fixações visuais e tomada de decisão 
Content validity of scenes from declarative tactical knowledge test for attack situation in beach... Jarbas Rállison Domingos-Gomes • Raianne de Brito Grisi • Júlio Cesar Gomes da Silva • Vitor Bruno Cavalcanti Torres • Henrique de Oliveira Castro • Gilmário Ricarte Batista

de atletas de voleibol das categorias infanto e juvenil. Revista Brasileira de Ciência e Movimento, v. 25, n. 1, p. 51-59, 2017. DOI: $10.18511 /$ rbcm.v25i1.6337.

CASTRO, H.O.; MORALES, J.C.P.; ABURACHID, L.M.C.; GRECO, P.J. Teste de conhecimento tático processual $3 \times 3$ com os pés : alternativa para a orientação esportiva. Revista Brasileira de Educação Física e Esporte, v. 29, n. 4, p. 621-629, 2015. DOI: 10.1590/1807-55092015000400621

CASTRO, H.O.; PRAÇA, G.M.; COSTA, G.C.T.; PEDROSA, G.F.; GRECO, P.J. Visual behavior and the quality of decision making on Volleyball. Revista Brasileira de Cineantropometria e Desempenho Humano, v. 18, n. 6, p. 638-647, 2016. DOI: 10.5007/1980-0037.2016v18n6p638.

COSTA, G.C.; CASTRO, H.O.; MESQUITA, I.R.; AFONSO, J.; LAGE, G.M.; UGRINOWITSCH, H.; PRAÇA, G.M.; GRECO, P.J. Tactical Knowledge, Decision-Making, and Brain Activation Among Volleyball Coaches of Varied Experience. Perceptual and Motor Skills, v. 125, n. 5, p. 951-965, 2018a. DOI: 10.1177/0031512518789582

COSTA, G. D. C. T.; CASTRO, H.O.; CABRAL, F.A.; MORALES, J.C.P.; GRECO, P.J. Content Validity of scenes of the Declarative Tactical Knowledge Test in Volleyball - DTKT:Vb. Revista Brasileira de Cineantropometria e Desempenho Humano, v. 18, n. 6, p. 629-637, 2016. DOI 10.5007/1980-0037.2016v18n6p629 COSTA, G.C.T.; CASTRO, H.O.; MESQUITA, I.M.R.; AFONSO, J.; LAGE, G.M.; GRECO, P.J. Visual Search and Decision-Making of Volleyball Coaches. Journal of Physical Education, v. 29, n. 1, p. 1-6, 2018b. DOI: 10.4025/jphyseduc.v28i1.2934

COSTA, J. C.; GARGANTA, J.; FONSECA, A. Inteligência e conhecimento específico em jovens futebolistas de diferentes níveis competitivos. Revista Portuguesa de Ciências do Desporto, v. 2, n. 4, p. 7-20, 2002.

ERICSSON, K. A. et al. The Crambridge handbook of Expertise and Expert Performance. New York: Cambridge University Press, 2006. 
Content validity of scenes from declarative tactical knowledge test for attack situation in beach... Jarbas Rállison Domingos-Gomes • Raianne de Brito Grisi • Júlio Cesar Gomes da Silva • Vitor Bruno Cavalcanti Torres • Henrique de Oliveira Castro • Gilmário Ricarte Batista

FRENCH, K.; THOMAS, J. The relation of knowledge development to children's basketball performance. Journal of Sport Psychology, v. 9, p. 15-32, 1987.

GAMERO, M.G.; GARCÍA-CEBERINO, J.M.; IBÁÑEZ, S.J.; FEU, S. Analysis of Declarative and Procedural Knowledge According to Teaching Method and Experience in School Basketball. Sustainability, v. 13, 6012, 2021. DOI: 10.3390/su13116012 GEORGE, G.; PANAGIOTIS, Z. Statistical Analysis of Men's FIVB Beach Volleyball Team Performance. International Journal of Performance Analysis in Sport, v. 8, n. 1, p. 31-43, 2008. DOI: 10.1080/24748668.2008.11868420

GIATSIS, G.; TZETZIS, G. Comparison of performance for winning and losing beach volleyball teams on different court dimensions. International Journal of Performance Analysis in Sport, v. 3, n. 1, p. 65-74, 2003. DOI: 10.1080/24748668.2003.11868276 GRECO, P.J.; Conhecimento tático-técnico: eixo pendular da ação tática (criativa) nos jogos esportivos coletivos. Revista Brasileira de Educação Física e Esporte, v.20, n. 5, p.210-212, 2006 GRECO, P. J.; ABURACHID, L.M.; SILVA, S.R.; MORALES, J.C.P. Content validation of tactical-technical actions of the Tactical Procedure Knowledge Test - Sporting Orientation. Motricidade, v. 10, n. 1, p. 38-48, 2014. DOI: 10.6063/motricidade.10(1).2124 GRISI, R.B.; TORRES, V.B.C.; SILVA, J.C.G.; MARANHÃO, J.F.S.; CASTRO, H.O.; BATISTA, G.R. Efeito de diferentes métodos de treinamento sobre o desempenho tático-técnico e a tomada de decisão de atletas masculinos do voleibol de praia. Journal of Physical Education, v. 32, e3234, 2021. DOI: 10.4025/jphyseduc. v32i1.3234

HERNÁNDEZ-NIETO, R. A. Contributions to statistical analysis. Mérida:Universidade de los Andes, 2002.

MCPHERSON, S. L.; THOMAS, J. R. Relation of knowledge and performance in boys' tennis: Age and expertise. Journal of Experimental Child Psychology, v. 48, n. 2, p. 190-211, 1989. DOI: 10.1016/0022-0965(89)90002-7 
Content validity of scenes from declarative tactical knowledge test for attack situation in beach... Jarbas Rállison Domingos-Gomes • Raianne de Brito Grisi • Júlio Cesar Gomes da Silva • Vitor Bruno Cavalcanti Torres • Henrique de Oliveira Castro • Gilmário Ricarte Batista

MESQUITA, I.; TEIXEIRA, J. Caracterização do processo ofensivo no voleibol de praia masculino de elite mundial, de acordo com o tipo de ataque, a eficácia e o momento do jogo. Revista Brasileira de Ciências do Esporte, v. 26, n. 1, p. 33-49, 2004. MORALES, J. C. P.; GRECO, P. J.; ANDRADE, R. L. Validade de Conteúdo do Instrumento para Avaliação do Conhecimento Tático Processual no Basquetebol. Cuadernos de Psicología del Deporte, v. 12, n. S1, p. 31-35, 2012.

MURGIA, M. et al. Using perceptual home-training to improve anticipation skills of soccer goalkeepers. Psychology of Sport and Exercise, v. 15, n. 6, p. 642-648, 2014. DOI: 10.1016/j.psychsport.2014.07.009

PALAO, J. M.; ORTEGA, E. Skill efficacy in men's beach volleyball. International Journal of Performance Analysis in Sport, v. 15, n. 1, p. 125-134, 2015. DOI: 10.1080/24748668.2015.11868781 PASQUALI, L. Instrumentos psicológicos: manual prático de elaboração. Brasília: Prática Gráfica e Editora, 1999.

PASQUALI, L. Validade dos testes psicológicos: será possível reencontrar o caminho? Psicologia: Teoria e Pesquisa, v. 23, n. especial, p. 99-107, 2007. DOI: 10.1590/s0102-37722007000500019 RAAB, M. Decision making in sports: Influence of complexity on implicit and explicit learning. International Journal of Sport and Exercise Psychology, v. 1, n. 4, p. 406-433, 2003. DOI: 10.1080/1612197X.2003.9671728

RAAB, M. Think SMART, not hard-a review of teaching decision making in sport from an ecological rationality perspective. Physical Education \& Sport Pedagogy, v. 12, n. 1, p. 1-22, 2007. DOI: $10.1080=17408980601060184$

RAAB, M. SMART-ER: A Situation Model of Anticipated Response consequences in Tactical decisions in skill acquisition - Extended and Revised. Frontiers in Psychology, v. 5, n. Article 1533, p. 1-5, 2015. DOI: 10.3389/fpsyg.2014.01533

RAAB, M.; GIGERENZER, G. Intelligence as smart heuristics. In: R. J. Sternberg, J. Davidson \& J. Pretz (Eds.). Cognition and intelligence. Cambridge: Cambridge University Press, 2005. p. 188-207. 
Content validity of scenes from declarative tactical knowledge test for attack situation in beach... Jarbas Rállison Domingos-Gomes • Raianne de Brito Grisi • Júlio Cesar Gomes da Silva • Vitor Bruno Cavalcanti Torres • Henrique de Oliveira Castro • Gilmário Ricarte Batista

RIBAS, S.; ABURACHID, L.M.C.; MORALES, J.C.P.; MONTEIRO, G.N.; PRAÇA, G.M.; CASTRO, H.O.; GRECO, P.J. Content validity evidences in the motor coordination test with ball. Revista Brasileira de Cineantropometria e Desempenho Humano, v. 22, e72376, 2020. DOI: 10.1590/1980-0037.2020v22e72376

ROBERTS, P.; PRIEST, H.; TRAYNOR, M. Reliability and validity in research. Nursing Standard, v. 20, n. 44, p. 41-45, 2006. DOI:10.7748/ns2006.07.20.44.41.c6560

TENENBAUM, G.; FILHO, E. Decision-Making in Sports: A Cognitive and Neural Basis Perspective. In: Reference Module in Neuroscience and Biobehaviour Psychology: Elsevier, 2017. DOI: 10.1016/B978-0-12-809324-5.05526-7

TILP, M., WAGNER, H., \& MÜLLER, E. (2008). Differences in 3D kinematics between volleyball and beach volleyball spike movements. Sports Biomechanics, v. 7, n. 3. p. 386-397. DOI: 10.1080/14763140802233231

WILLIAMS, M.; DAVIDS, K. Declarative knowledge in sport: A by-product of experience or a characteristic of expertise? Journal of Sport and Exercise Psychology, v. 17, n. 3, p. 259-275, 1995. DOI: 10.1123/jsep.17.3.259

WILLIAMS, A. M. et al. Perceptual-cognitive expertise, practice history profiles and recall performance in soccer. British Journal of Psychology, v. 103, n. 3, p. 393-411, 2012. DOI:10.1111/j.20448295.2011.02081.x

\section{Publisher}

Universidade Federal de Goiás. Faculdade de Educação Física e Dança. Publicação no Portal de Periódicos UFG. As ideias expressadas neste artigo são de responsabilidade de seus autores, não representando, necessariamente, a opinião dos editores ou da universidade. 